\title{
A Review of the Biology of Eucharitidae (Hymenoptera: Chalcidoidea) from Argentina
}

\author{
Javier Torréns \\ CRILAR-CONICET, Entre Ríos y Mendoza, 5301 Anillaco, La Rioja, Argentina \\ Correspondence should be addressed to Javier Torréns; jtorrens@crilar-conicet.gob.ar
}

Received 3 March 2013; Revised 30 April 2013; Accepted 12 May 2013

Academic Editor: Jean-Paul Lachaud

Copyright (c) 2013 Javier Torréns. This is an open access article distributed under the Creative Commons Attribution License, which permits unrestricted use, distribution, and reproduction in any medium, provided the original work is properly cited.

\begin{abstract}
All the members of Eucharitidae are parasitoid of ants. Argentina has 14 genera and 41 species, but little is known about their biology. Herein are provided new data for host associations (host ant and/or host plant) of Galearia latreillei, Kapala spp., Latina rugosa, Orasema aenea, and Orasema sp. A revision of the most relevant biological aspects of Dicoelothorax platycerus, Latina rugosa, Neolirata alta, $N$. daguerrei, Lophyrocera variabilis, Orasema argentina, O. salebrosa, O. simplex, O. susanae, O. worcesteri, and O. xanthopus is included. New records of K. sulcifacies, Lo. plagiata, and Ob. semifumipennis in Argentina are presented. Galearia proseni is synonymized with $G$. latreillei.
\end{abstract}

\section{Introduction}

Eucharitidae parasitize the immature stages of Formicidae and are among the most diverse hymenopteran parasitoids of eusocial insects [1-8]. Females are oviparous and proovigenic and lay their eggs inside or on plant tissues, either individually or in masses. They oviposit away from the host, with the active first instar larva (planidium) responsible for getting into the ant nest through various associations with foraging adult ants [9]. Once in contact with the larval ant host, the planidium either remains as an external parasite or burrows into the host. Upon pupation of the host, the larva migrates to the ventral region of the thorax, just posterior to the legs of the newly formed pupa, then resumes development through two additional instars $[10,11]$. The adults emerge and leave the nest on their own or may be carried by the ants and deposited in the accumulation of colony waste $[10,12,13]$.

Eucharitidae are present in all zoogeographic regions but most abundant in the tropics [8]. Fifty-four genera and about 420 species worldwide have been described. In Argentina, 14 genera and 41 species have been reported [8, 14-16].

Eucharitidae were well studied in a series of early taxonomic papers by Gemignani [17-19]; however, very little information was provided on their biology. This paper reviews our current understanding and contributes new data for some of the Argentinean species.

\section{Materials and Methods}

Females were collected by sweep netting and provided twigs with leaves, fruits, and flowers of different species of plants in $10 \times 3.5 \mathrm{~cm}$ plastic tubes to monitor oviposition habits. Host plants with eggs extracted from the field or oviposited by the captive females were placed into a cylindrical glass container of $10 \times 10 \mathrm{~cm}$ with dampened cotton until emergence of the first instar (planidium).

Ant nests with adults, brood, and debris were collected into plastic containers. Adults and immature stages were then sorted from the debris, examined for parasitism, and in some cases returned to the containers to allow further development of immature ones. The immature stages were examined once daily until all parasitoids or ants emerged from the cocoons. In the cases where both parasitoid sexes emerged, they were put together in a cylindrical glass container of $10 \times 10 \mathrm{~cm}$ containing different types of plants to allow for oviposition after mating.

A Leica MZ12 stereomicroscope was used for observations. Images were obtained using GT-Vision Ento-Vision software operating on a Leica M16 zoom lens linked to a JVC KY-F75U 3-CCD digital video camera or Leica Application Suite (version 3.5.0) software operating on a Leica MZ12 linked to a Leica DFC295 digital video camera. Images were 
enhanced with Corel Photopaint and Corel Draw (version 15). Some images were processed using Deep Focus (Stuart Ball).

The biogeographical distribution and classification of ecoregions in Argentina was taken from Morrone [20] and Bertonatti and Corcuera [21]. Geographic coordinates for eucharitid localities were estimated using Google Earth (version 6.2.2.6613).

\section{Genera and Species of Eucharitidae from Argentina}

Two of the four subfamilies of Eucharitidae are represented in Argentina, Oraseminae and Eucharitinae (Table 1). Oraseminae is represented only by Orasema Cameron. The Eucharitinae are comprised of 12 genera of Eucharitini with a dubious record of Psilocharis Heraty (Psilocharitini) from Déan Funes (Córdoba) [5].

3.1. Dicoelothorax Ashmead. This genus includes two species distributed in the Neotropical region: D. parviceps Cameron (Argentina, Brazil, Colombia, and Guyana) and D. platycerus Ashmead (Argentina, Bolivia, and Brazil) (Figures 1(a) and $1(b))[8,14,22]$. Biological information is only available for D. platycerus [22].

3.1.1. Dicoelothorax platycerus Ashmead. Habitat and location are as follows. Specimens were collected in San Vicente (Tucumán). The vegetation of this region is characterized by dry forests, dominated by deciduous, spiny, and smallleaves plants typical of the Chaco ecoregion [40] (Figures $1(\mathrm{c})$ and $1(\mathrm{~d})$ ). The host plant, Pseudabutilon virgatum (Cav.) (Malvaceae), is a ligneous shrub that occurs throughout the area and persists year round.

Life history and host ants are next. A single gravid female oviposited about 40 eggs per $1 \mathrm{~mm}^{2}$ on the underside of leaves (Figure 1(e)), and eggs hatched within 10 days. First instars (planidia) (Figure 1(f)) are mobile and have a propensity to jump; larvae presumably attach phoretically to foraging ants under the host plant and get carried back to the ant nest where they attack the ant larvae [3]. Of two pupae of D. platycerus obtained from the host ants nest one male emerged 12 days after the nest was excavated, whereas the other pupa (female) did not emerge (Figure 2(d)).

Ectatomma brunneum F. Smith (Ectatomminae) workers were observed and sampled from under the plants with Dicoelothorax. Of three ant nests found, immature ones were in two of them ( $\mathrm{H} 1$ and $\mathrm{H} 2)$. The disposition of chambers and general structure of nests are similar to those observed by Lapola et al. [41] (Figures 1(g) and 2(a)). Nest H1 contained 17 cocoons and 2 ant larvae, and nest $\mathrm{H} 2$ had 97 ant larvae and no cocoons. The percentage of parasitism ranged from $6.2 \%$ in $\mathrm{H} 2$ to $21 \%$ in $\mathrm{H} 1$. Of the 17 cocoons ( $\mathrm{H} 1)$ recovered, there were two cocoons each with one pupae of $D$. platycerus ( 1 female and 1 male) and 2 ant prepupae parasitized by second instars of $D$. platycerus (Figure 2(b)). In nest H2, 6 of the larvae were parasitized by externally located planidia (Figure 2(c)).
3.2. Galearia Brullé. The genus is comprised of two species, G. latreillei (Guérin-Méneville) and G. proseni Gemignani. Heraty [8] argued that the Argentinean male described as $G$. proseni by Gemignani [19] was likely the male of G. latreillei (Figures 2(e) and 2(f)). Based on the morphological similarity of a reared male with $G$. proseni (=Pseudokapala proseni), and its subsequent mating with a female of $G$. latreillei, $I$ infer that the suggestion by Heraty is correct and propose here a new synonymy of $G$. proseni with $G$. latreillei. The one species has a widespread Neotropical distribution, being present in Argentina, Bolivia, Brazil, and Venezuela [8, 14].

The only known biological record was from Gemignani [17] in which he mentioned that an adult of G. latreillei (=Thoracantha latreillei) was collected from the waste pile of a nest of Pogonomyrmex cunicularius Mayr (=P. carnivora), but this ant association is likely invalid [8].

Galearia latreillei was collected in northcentral and northwestern Argentina, and information on life history, immature stages, and host association is included.

3.2.1. Galearia latreillei (Guérin-Méneville). Habitat and locations are as follows. Specimens were collected in Cabeza de Buey (Salta), Campo Gallo, Suncho Corral, and Tintina (Santiago del Estero). The Cabeza de Buey locality consists of mixed yunga (humid mountain forest) and xeric lowland Chaco vegetation. In the two localities in Santiago del Estero, located in the center and north of the province, the vegetation is typical of the chaco ecoregion (Figure 3(a)). The host plant, Sida cordifolia L. (Malvaceae), is a perennial, herbaceous plant with stems that are yellow-green, hairy, long, and slender, and their leaves are oblong-ovate, covered with hairs (Figure 3(b)).

Life history and host ants are next. Both sexes of $G$. latreillei were obtained from a nest of Ectatomma brunneum. The adult wasps were together for two days before mating occurred. The female then oviposited about 400 eggs that were dispersed among the spicules forming the pubescence on the stem of $S$. cordifolia near to the leaves or in the underside of leaves near the base (Figure 3(c)). Eggs hatched within 11 days. The planidia were very mobile and had a propensity to jump.

Nests of Ectatomma brunneum were excavated from near to the host plant, with immature ones found at a depth of 6 to $8 \mathrm{~cm}$. From 50 cocoons, we extracted 10 pupae of $G$. latreillei. One male and one female emerged about 4 days after the nest was excavated, whereas the other pupae did not emerge (Figure 3(f)). Three other cocoons yielded one second-instar and two third-instars (Figures 3(d) and 3(e)). Of the 50 cocoons recovered, 13 were attacked giving a percentage parasitism of $26 \%$.

Discussion. Ectatomma brunneum has also been reported as the ant host for Dicoelothorax platycerus [22] and for an unidentified species of Kapala Cameron (Eucharitidae: Eucharitini) in French Guiana [42]. Similarly, another species of the same ant genus, E. tuberculatum (Olivier), is known to be attacked by three different eucharitid genera, Dilocantha Shipp, Isomerala Shipp, and Kapala [43]. 
TABLE 1: List of species of Eucharitidae in Argentina. Known biology is indicated for host ants (HAs), host plants (HPs), or immature stages (ISs).

\begin{tabular}{|c|c|c|c|}
\hline Subfamilies/tribes/genera & Species & Biology & References \\
\hline \multicolumn{4}{|l|}{ Eucharitinae } \\
\hline \multicolumn{4}{|l|}{ Psilocharitini } \\
\hline Psilocharis Heraty & Psilocharis sp. ${ }^{*}$ & $?$ & - \\
\hline \multicolumn{4}{|l|}{ Eucharitini } \\
\hline Colocharis Heraty & Colocharis hungi Torréns & $?$ & - \\
\hline \multirow{2}{*}{ Dicoelothorax Ashmead } & Dicoelothorax parviceps Cameron & $?$ & - \\
\hline & Dicoelothorax platycerus Ashmead & HP, HA, IS & {$[22]$} \\
\hline \multirow{2}{*}{ Dilocantha Shipp } & Dilocantha bennetti Heraty & $?$ & - \\
\hline & Dilocantha flavicornis (Walker) & $?$ & - \\
\hline Galearia Brullé & Galearia latreillei (Guérin-Méneville) & HP, HA, IS & $* * *$ \\
\hline \multirow{5}{*}{ Kapala Cameron } & Kapala argentina Gemignani & $?$ & - \\
\hline & Kapala chacoensis Gemignani & ? & - \\
\hline & Kapala furcata (Fabricius) & $\mathrm{HP}$ & {$[2,3]$} \\
\hline & Kapala splendens Ashmead & $?$ & - \\
\hline & Kapala sulcifacies (Cameron) ${ }^{* *}$ & HP, IS & {$[23,24]$} \\
\hline \multirow{2}{*}{ Latina Koçak \& Kemal } & Latina bonariensis (Gemignani) & $?$ & - \\
\hline & Latina rugosa (Torréns, Heraty \& Fidalgo) & HP, HA, IS & {$[25], \mathrm{HA}^{* * *}$} \\
\hline \multirow{5}{*}{ Lophyrocera Cameron } & Latina vianai (Gemignani) & $?$ & - \\
\hline & Lophyrocera daguerrei (Gemignani) & $?$ & - \\
\hline & Lophyrocera plagiata (Walker) ${ }^{* *}$ & $?$ & - \\
\hline & Lophyrocera variabilis Torréns, Heraty \& Fidalgo & HP, HA, IS & {$[26]$} \\
\hline & Neolirata alta (Walker) & HP, IS & {$[15]$} \\
\hline \multirow[t]{2}{*}{ Neolirata Torréns \& Heraty } & Neolirata daguerrei (Gemignani) & HP, IS & {$[15]$} \\
\hline & Neolirata furcula Torréns \& Heraty & $?$ & - \\
\hline \multirow[t]{3}{*}{ Obeza Heraty } & Obeza maculata (Westwood) & $?$ & - \\
\hline & Obeza nigriceps (Ashmead) & $?$ & - \\
\hline & Obeza semifumipennis (Girault) ${ }^{* *}$ & $?$ & - \\
\hline \multirow[t]{3}{*}{ Parakapala Gemignani } & Parakapala decarloi Gemignani & $?$ & - \\
\hline & Pseudochalcura alba Heraty \& Heraty & $?$ & - \\
\hline & Pseudochalcura americana (Howard) & $?$ & - \\
\hline \multirow[t]{3}{*}{ Pseudochalcura Ashmead } & Pseudochalcura frustrata Heraty & $?$ & - \\
\hline & Pseudochalcura pauca Heraty & $?$ & - \\
\hline & Pseudochalcura prolata Heraty & $?$ & - \\
\hline \multirow{2}{*}{ Thoracantha Latreille } & Thoracantha spegazzinii (Gemignani) & HP & {$[17]$} \\
\hline & Thoracantha striata Perty & HP, IS & {$[8]$} \\
\hline \multicolumn{4}{|l|}{ Oraseminae } \\
\hline \multirow{11}{*}{ Orasema Cameron } & Orasema aenea Gahan & HP, HA, IS & $* * *$ \\
\hline & Orasema argentina Gemignani & HA & {$[6,17]$} \\
\hline & Orasema deltae Gemignani & $?$ & - \\
\hline & Orasema freychei (Gemignani) & $?$ & - \\
\hline & Orasema gemignanii De Santis & $?$ & - \\
\hline & Orasema salebrosa Heraty & HA & {$[11,27]$} \\
\hline & Orasema simplex Heraty & HA, HP & {$[11,28,29]$} \\
\hline & Orasema susanae Gemignani & HA & {$[6]$} \\
\hline & Orasema vianai Gemignani & $?$ & - \\
\hline & Orasema worcesteri (Girault) & HA & [17] \\
\hline & Orasema xanthopus (Cameron) & HP, HA, IS & {$[6,11,27,28,30-39]$} \\
\hline
\end{tabular}

Abbreviations: ${ }^{*}$ doubtful record [5]; ${ }^{* *}$ new record of presence in Argentina; ${ }^{* * *}$ new biological record. 


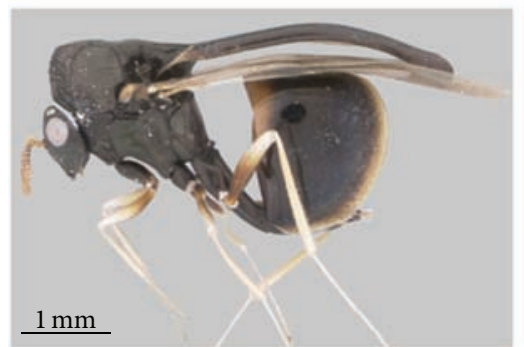

(a)

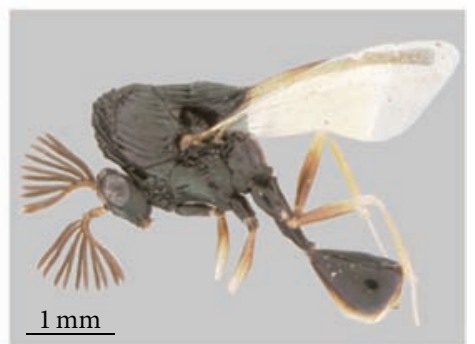

(b)

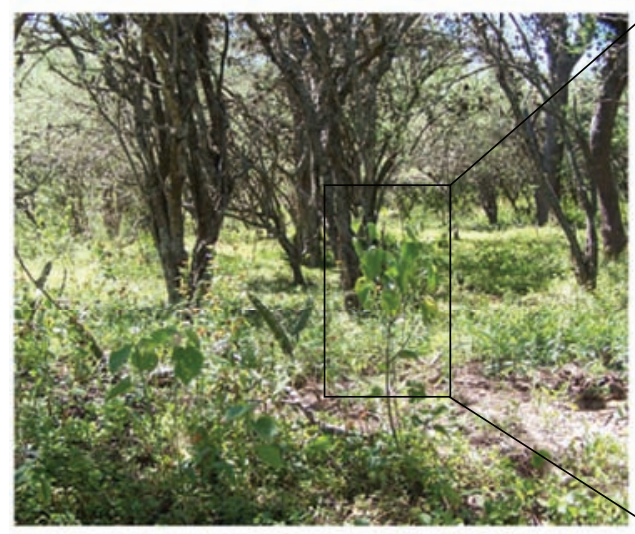

(c)

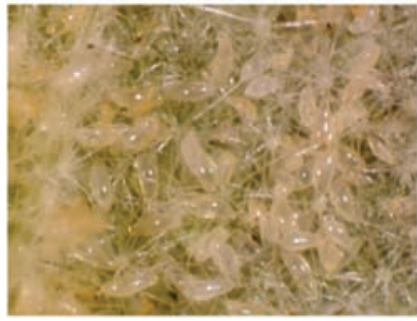

(e)

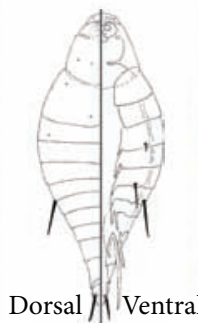

(f)

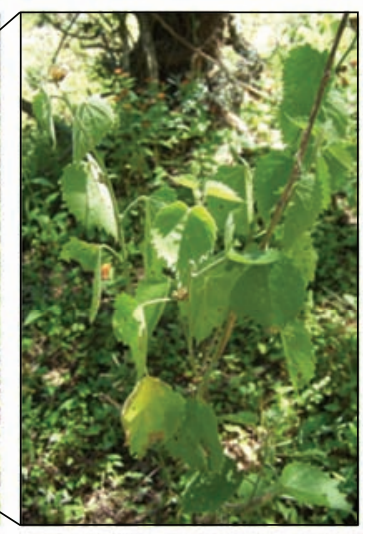

(d)

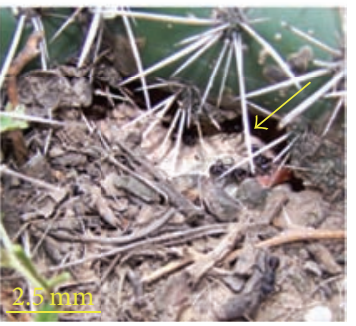

(g)

FIGURE 1: Dicoelothorax platycerus: (a) habitus (female); (b) habitus (male). Biology and immature stage of D. platycerus: (c) habitat; (d) Pseudabutilon virgatum; (e) underside of leaf of $P$. virgatum with eggs; (f) planidium (dorsal and ventral); (g) nest entrance of Ectatomma brunneum (opening indicated). Figures extracted from [22].

3.3. Kapala Cameron. Kapala includes 16 species, but there are many undescribed species in the Neotropical region. It is widespread and diverse in both the Nearctic and Neotropical regions and also includes one widespread afrotropical species, Kapala ivorensis Risbec [8].

In Argentina, 5 species were recorded: $K$. argentina Gemignani, K. chacoensis Gemignani, K. furcata (Fabricius), K. splendens Ashmead, and K. sulcifacies (Cameron) [8, 14]. Partial biological information is available for $K$. furcata and K. sulcifacies (summarized later). New data is also added for two unidentified species.

3.3.1. Kapala furcata (Fabricius). This species was observed ovipositing on floral buds of Mikania sp. (Asteraceae) [2] that were infested with aphids [3].
3.3.2. Kapala sulcifacies (Cameron). This species has been reported as ovipositing in floral buds of Cordia curassavica (Jacq.) Roem. \& Schult. (Boraginaceae) (=Cordia macrostachya), Gossypium hirsutum L. (Malvaceae), and in a flowering asclepiad [23], with eggs laid in clusters of 200-300 eggs [24].

3.3.3. Kapala spp. A species sampled in Campo Gallo (Santiago del Estero) oviposited into flower buds of Sphaeralcea bonariensis (Cav.) Griseb. (Malvaceae), with the planidia emerging 9 days after oviposition. Another species was collected in Rosario de la Frontera (Salta) over an unidentified Sapindaceae, but no oviposition was observed.

3.4. Latina Koçak and Kemal. Latina (=Laurella Heraty) includes four species distributed in the Neotropical 


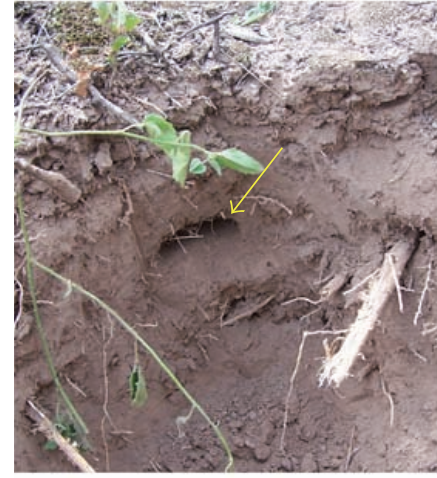

(a)

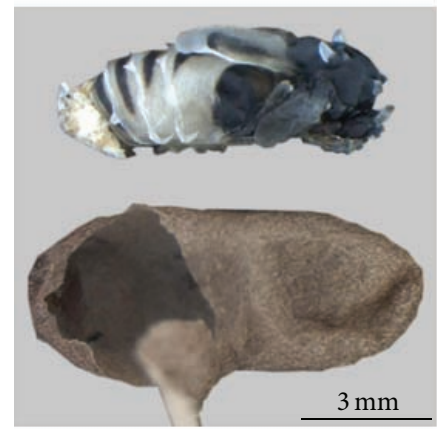

(d)

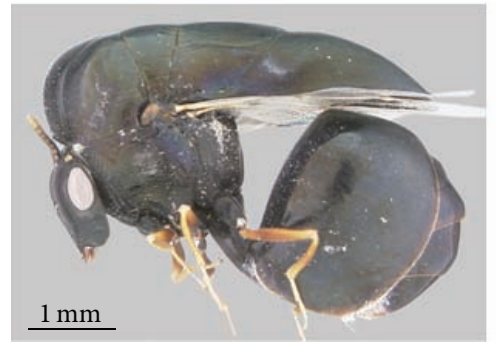

(e)

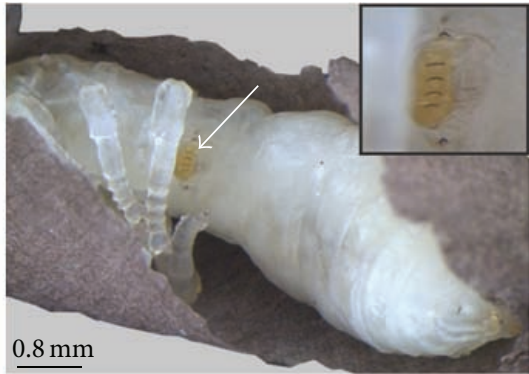

(b)

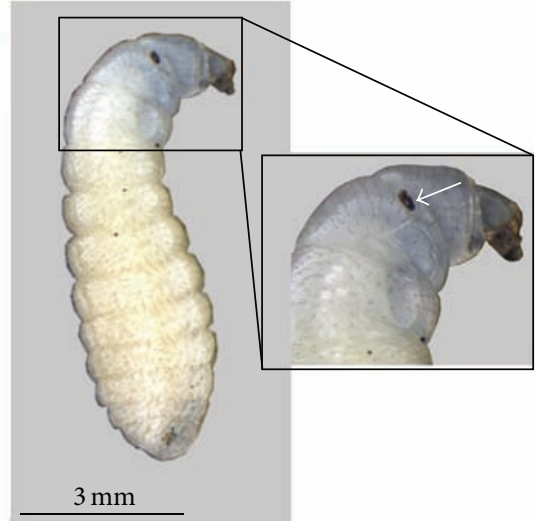

(c)

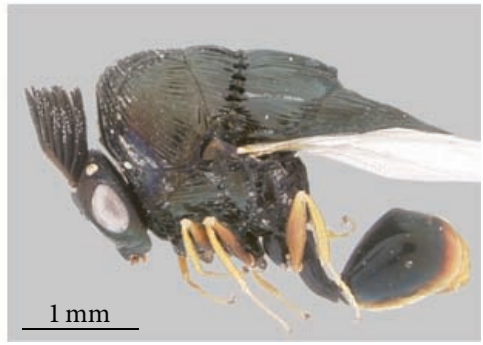

(f)

FIGURE 2: Biology and immature stage of D. platycerus: (a) brood chamber (indicated); (b) prepupa parasitized (2nd instar larva indicated and magnified); (c) ant larva parasitized (attached planidium magnified and indicated); (d) pupa extracted with ant cocoon (female, lateral). Galearia latreillei: (e) habitus (female); (f) habitus (male). Figures 2(a), 2(b), 2(c), and 2(d) are extracted from [22].

region: Latina bonariensis (Gemignani) (Argentina), L. guriana (Heraty) (Venezuela), L. rugosa (Torréns, Heraty and Fidalgo) (Argentina) (Figures 4(a) and 4(b)), and L. vianai (Gemignani) (Argentina) $[8,25]$.

Latina rugosa was collected in northwestern Argentina and the taxonomic and biological aspects provided by Torréns, Heraty, and Fidalgo [25].

3.4.1. Latina rugosa (Torréns, Heraty, and Fidalgo). Habitat and location are as follows. Specimens were collected at Rosario de la Frontera (Salta); the collection site was a forest of Piptadenia macrocarpa Benth. (Cebil Colorado) (Fabaceae). The vegetation of this region corresponds to the Yungas and Chaco ecoregions [40]. The host plants, Serjania glabrata (Sapindaceae), are perennial shrubs with pubescent and serrated leaves, with the plants dispersed between trees in the collection area (Figures 4(c) and 4(d)).

Life history and host ants are next. Adults of L. rugosa were collected in the same location, mainly close to or on the host plant. A single gravid female oviposited about 25 eggs per $1 \mathrm{~mm}^{2}$ on the underside of leaves (Figure 4(d)). Eggs hatched within 6 days. The planidia (Figure 4(e)) were mobile and able to jump.

Odontomachus chelifer (Latreille) (Ponerinae) workers were observed and collected under the host plants from which $L$. rugosa were collected. One $O$. chelifer nest was identified only by a small ground opening. The ant nests were excavated and the cocoons and ants larvae extracted at a depth of $16 \mathrm{~cm}$; however, the nest appeared to be much deeper, and it was difficult to tell whether the entire brood was extracted. Of the five ant larvae extracted, one had three 


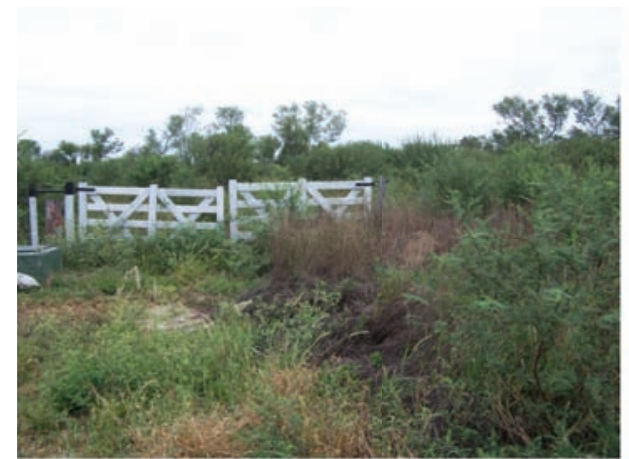

(a)

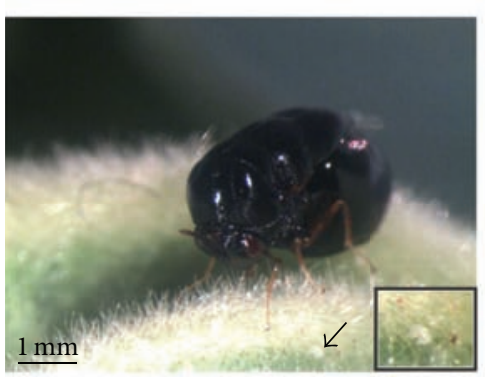

(c)

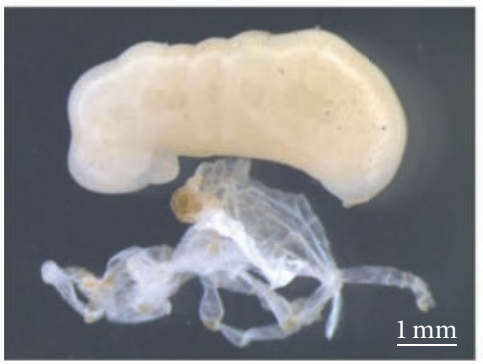

(e)

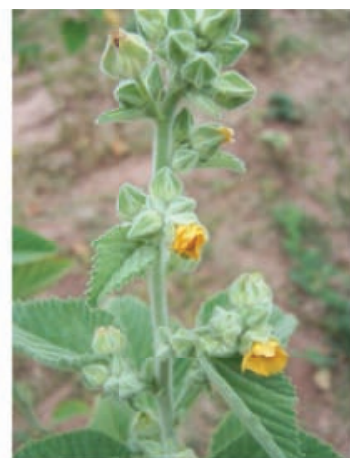

(b)

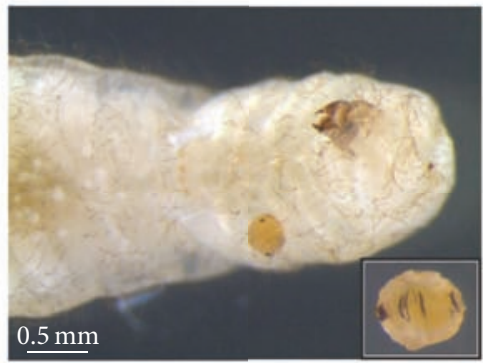

(d)

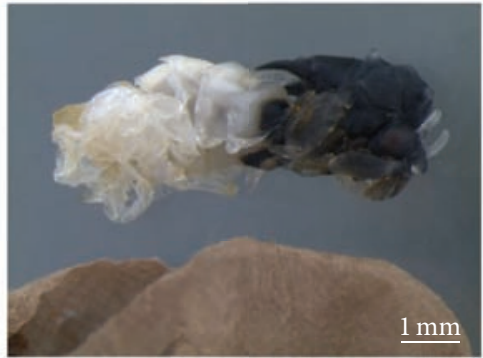

(f)

Figure 3: Biology and immature stage of Galearia latreillei: (a) habitat; (b) Sida cordifolia; (c) female of G. latreillei ovipositing on leaf of S. cordifolia (eggs indicated and magnified); (d) prepupa parasitized (1st instar larva indicated and magnified); (e) third instar (with remains of ant pupa); (f) pupa extracted from ant cocoon (male, lateral).

planidia externally attached (Figure 4(f)), while of the 19 cocoons only one planidium was found attached externally to a prepupa. From this sample, the percentage of parasitism was $8.3 \%$ of 24 immature ones.

Discussion. Data presented here confirm the ant host association of Latina rugosa as Odontomachus chelifer. This ant genus is also the host of other eucharitids genera as Ancylotropus Cameron, Chalcura Kirby, Schizaspidia Westwood, and Kapala Cameron [8, 42].

3.5. Lophyrocera Cameron. Lophyrocera Cameron includes seven species distributed across South and Central America and the western United States (Neotropical and Nearctic): L. apicalis Ashmead (USA), L. daguerrei (Gemignani)
(Argentina), L. chilensis (Brèthes) (Chile), L. plagiata (Walker) (Argentina and Brazil), L. pretendens (Walker) (Brazil), L. stramineipes Cameron (Panama), and L. variabilis Torréns et al. (Argentina) (Figures 5(a)-5(c)) [8, 14, 26].

Lophyrocera variabilis was collected in northwestern Argentina, with information available on life history, immature stages, and host association [26].

3.5.1. Lophyrocera variabilis Torréns, Heraty, and Fidalgo. Habitat and location are as follows. The habitat consists of mixed Yungas and Chaco vegetation in Los Chorrillos (Tucumán) (Figure 5(d)). The host plant, Vassobia breviflora (Sendtn) Hunz. (Solanaceae), common name "Chalchal de la gallina", is a spiny shrub with globe-shaped fruits, which are red in color when mature (Figure 5(e)) [44]. 


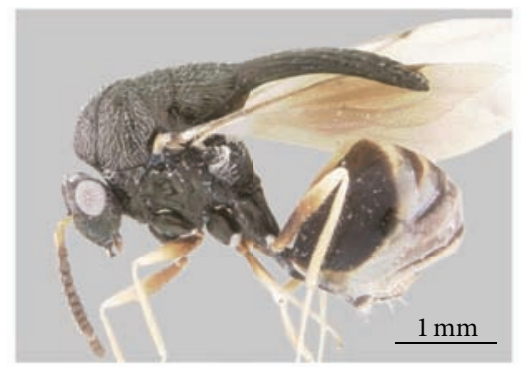

(a)

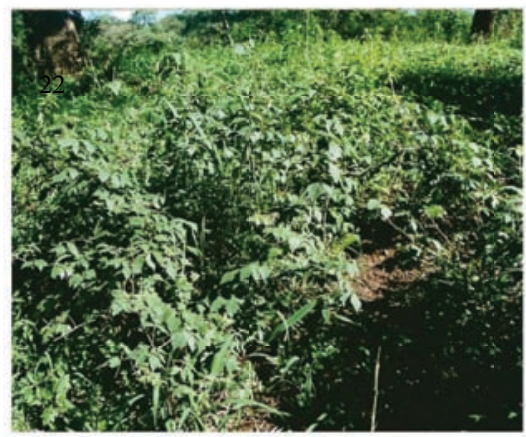

(c)

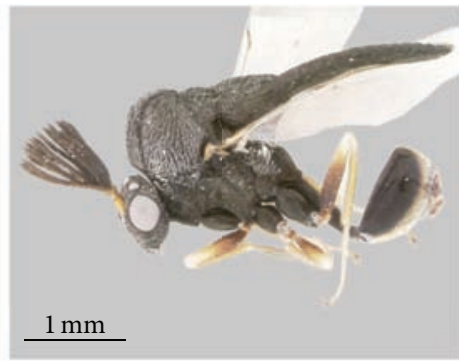

(b)

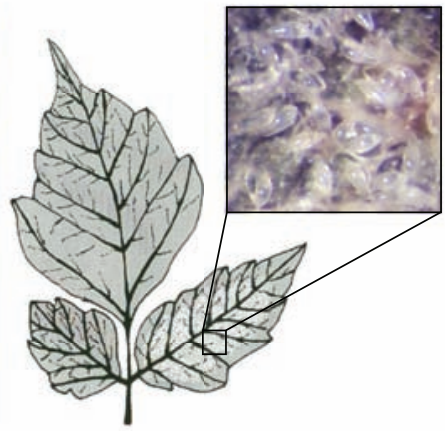

(d)

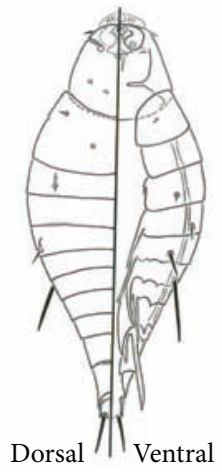

(e)

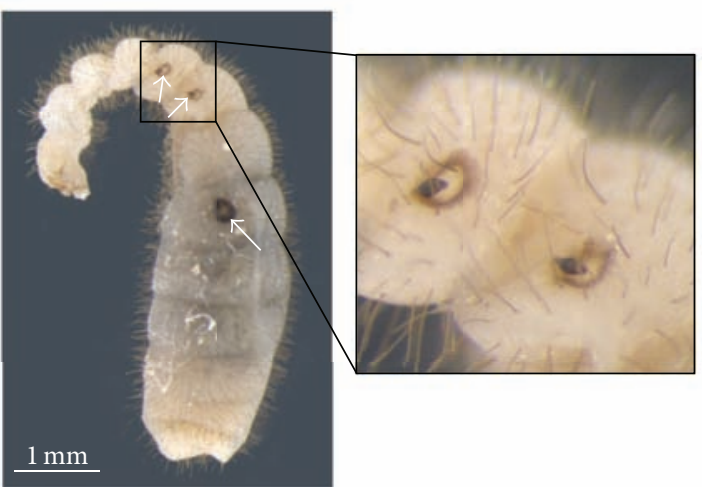

(f)

Figure 4: Latina rugosa: (a) habitus (female); (b) habitus (male). Biology and immature stage of L. rugosa: (c) habitat; (d) underside of leaf of Serjania glabrata with eggs (eggs represented in white area and magnified); (e) planidium (dorsal and ventral view); (f) ant larva parasitized (attached planidia magnified and indicated). Figures 4(d) and 4(e) are extracted from [25].

Life history and host ants are next. Females were observed ovipositing in the immature (green) fruit of $V$. breviflora, with eggs deposited in small masses within the fruit (Figure 5(f)). Only undeveloped eggs were obtained from immature fruits while mature fruits taken from the ground had mature eggs and larvae. The planidia (Figure 5(g)) crawl and do not have the ability to jump.

In the field, a species of Camponotus Mayr (Formicinae: Camponotini) visited and foraged below the host plant. Camponotus are known to collect fruit pulp and small seeds [45], and a direct interaction of foragers with the ripe fruit and planidia is very likely, as proposed for Pseudochalcura [9].

Nests of Camponotus were located under host plants or within a few meters (Figure 6(a)). In total, 35 Lophyrocera pupae were found in 7 of the 13 nests excavated, and of these, three had two pupae of $L$. variabilis in the same cocoon
(Figure 6(b)). No larvae were found. The parasitism rate ranged from 0 to $6.21 \%$.

3.6. Neolirata Torréns and Heraty. This genus includes three species distributed in the Neotropical region: N. alta (Walker) (Argentina, Brazil, and Uruguay) (Figure 6(c)), N. daguerrei (Gemignani) (Argentina, and Brazil) (Figures 7(a) and 7(b)), and N. furcula Torréns and Heraty (Brazil) [15].

Neolirata alta and $N$. daguerrei were collected in northwestern Argentina, and their taxonomic and biological information is given in Torréns and Heraty [15].

3.6.1. Neolirata alta (Walker). Habitat and location are as follows. Specimens were collected in Los Baños and Rosario de la Frontera (Salta) and Tapia and San Vicente (Tucumán). In Los Baños, the vegetation corresponds to the transition 


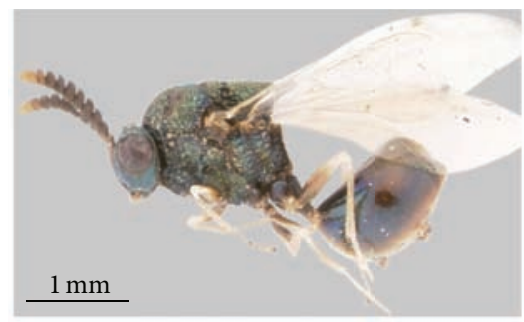

(a)

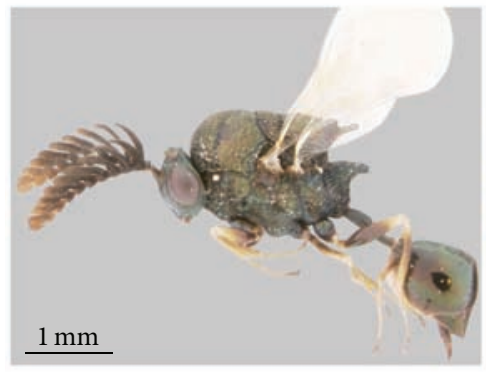

(c)

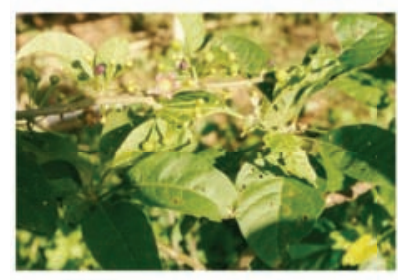

(e)

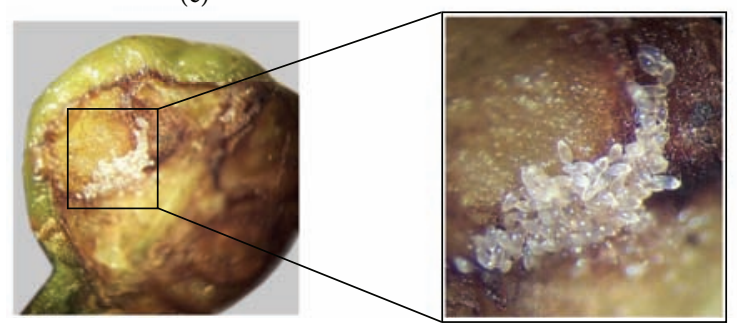

(f)

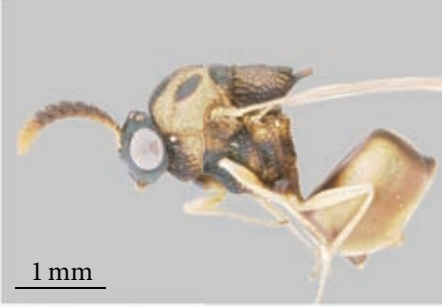

(b)

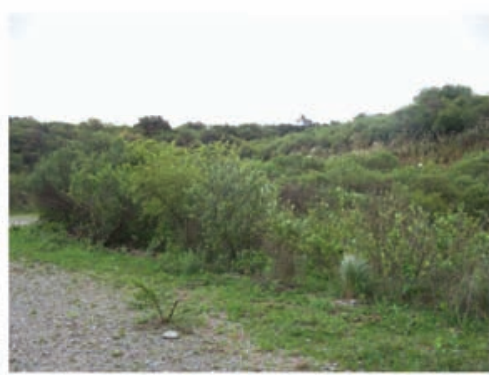

(d)

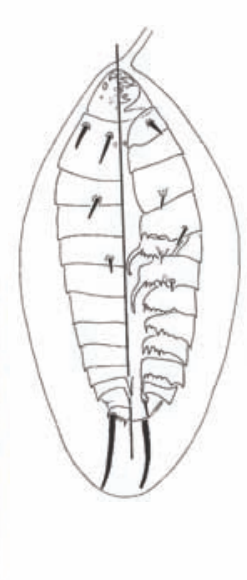

(g)

FIGURE 5: Lophyrocera variabilis: (a) and (b) habitus (female); (c) habitus (male). Biology and immature stages of L. variabilis: (d) habitat; (e) Vasobia breviflora; (f) saggittal section of unripe fruits of $V$. breviflora with eggs (egg mass magnified); (g) planidium (before hatching; dorsal and ventral view). Figures 5(a)-5(c), 5(f), and 5(g) are extracted from [26].

Yungas and Chaco ecoregions, while the others are typical of the Chaco ecoregion (Figure 6(d)). The host plant, Pseudabutilon virgatum, was widely distributed in all four areas (Figure 6(e)).

Life history and host ants are next. The female oviposited about 32 eggs per $\mathrm{mm}^{2}$ at random between the spicules on the underside of a leaf (Figure 6(e)). Eggs hatched within 14 days. The planidia (Figure 6(f)) were mobile and have the ability to jump.

The host ant remains unknown. A few meters from where the female was collected in San Vicente (Tucumán), there was a nest of Ectatomma brunneum. This nest was excavated, but no immature stages were found.

3.6.2. Neolirata daguerrei (Gemignani). Habitat and location are as follows. Most specimens were collected in Tapia
(Tucumán) (Figure 7(c)); the vegetation corresponds to the Chaco ecoregion [40]. The host plant, Urvillea chacoensis Hunz. (Sapindaceae), is a climbing vine distributed throughout the collection area; its leaves are marginally serrate and pubescent [46] (Figure 7(d)).

Life history and host ants are next. Females were observed ovipositing on the underside of leaves of $U$. chacoensis. A single gravid female oviposited about 28 eggs per $\mathrm{mm}^{2}$ (Figure 7(d)). Eggs hatched within 9 days (Figure 7(e)). Planidia (Figure $7(f)$ ) are very mobile and jump.

Host ant unknown.

3.7. Orasema Cameron. Orasema is composed of 57 species, but many are still undescribed. Their distribution is Neotropical, Nearctic, and Paleotropical [8]. In Argentina, Orasema is widely distributed, with 11 species documented: 


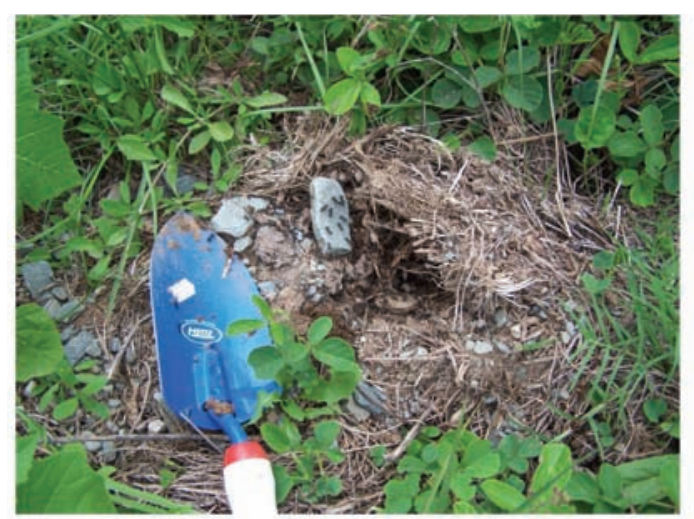

(a)

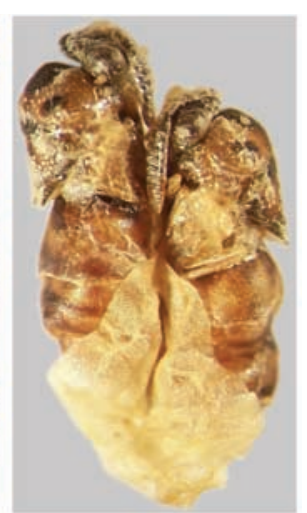

(b)

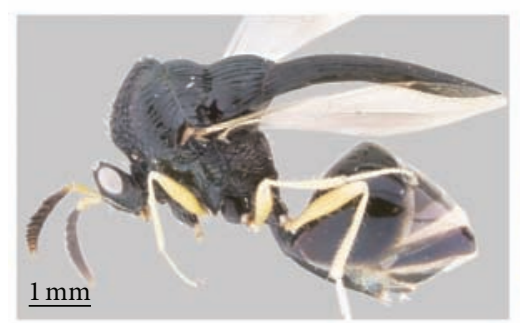

(c)

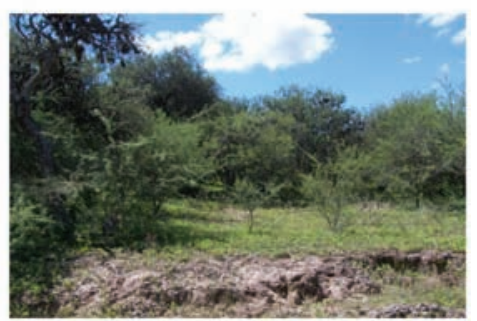

(d)

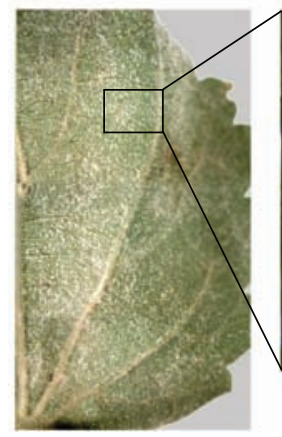

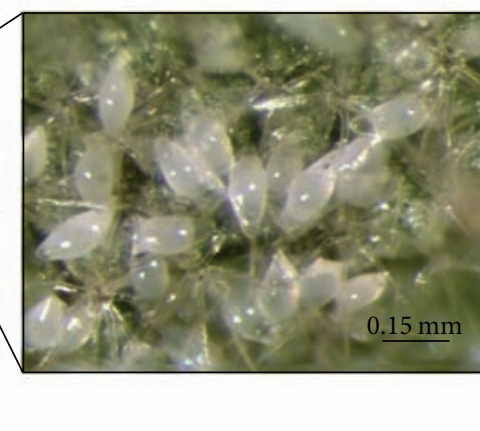

(e)

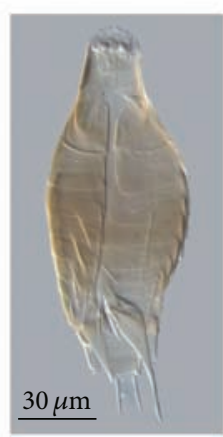

(f)

FIGURE 6: Biology and immature stage of Lophyrocera variabilis: (a) ant nest of Camponotus sp.; (b) two Lophyrocera pupae extract from same ant cocoon (females). Neolirata alta: (c) habitus (female). Biology and immature stage of N. alta: (d) habitat; (e) underside of leaf of P. virgatum with eggs (magnified area with eggs); (f) planidia. Figure 6(b) is extracted from [26], and Figures 6(c), 6(d), 6(e), and 6(f) are extracted from [15].

O. aenea Gahan, O. argentina Gemignani, O. deltae Gemignani, O. freychei (Gemignani), O. gemignanii De Santis, O. salebrosa Heraty, O. simplex Heraty, O. susanae Gemignani, O. vianai Gemignani, O. worcesteri (Girault), and O. xanthopus (Cameron).

Several authors have studied the biological aspects of Orasema [5, 7, 11, 27-29, 47-56]. Among the genera of ants recorded as attacked by Orasema are Formica Linnaeus, Monomorium Mayr, Pheidole Westwood, Solenopsis Westwood, Temnothorax Mayr, Tetramorium Mayr, Wasmannia Forel, and a dubious case of Eciton Latreille [5-8, 11, 27, 47, 54]. Immature stages were described by several authors [5$8,11,24,27,47,48,53,54,56,57]$.

Herein are summarized the most relevant data on the biology of the species found in Argentina, with new data for $O$. aenea and some records of an unidentified species.
3.7.1. Orasema aenea Gahan. Habitat and location are as follows. Specimens of O. aenea (Figures $8(\mathrm{a})$ and $8(\mathrm{~b})$ ) were collected in Caimancito (Jujuy). The vegetation and geographic location corresponds to the foothills of the Yungas ecoregion. The host plant, Tecoma stans (L.) Juss. ex Kunth (Bignoniaceae) (common name, Guarán amarillo), is a shrub or small tree that grows 3-6 m tall, with leaves decussate with elliptic-lanceolate and serrated edges, and it blooms from August to October [40] (Figure 8(c)).

Life history and host ants are next. Females were observed ovipositing on the undersides of leaves of T. stans by creating an incision and laying a single egg in short linear rows (Figures 8(d) and 8(e)). Eggs hatched within 9 days. Planidia (Figure 8(f)) crawl and leave the incision but do not have the ability to jump. 


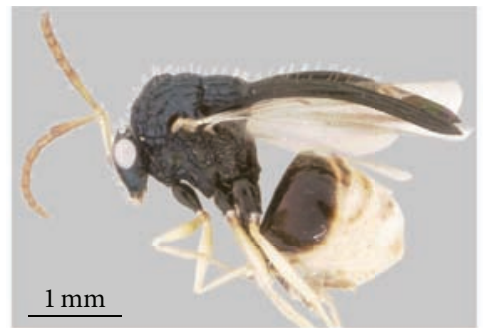

(a)

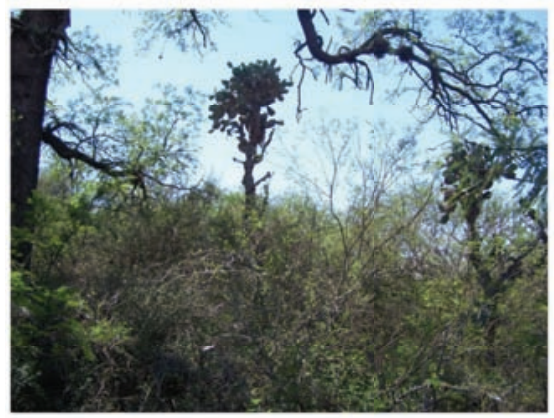

(c)

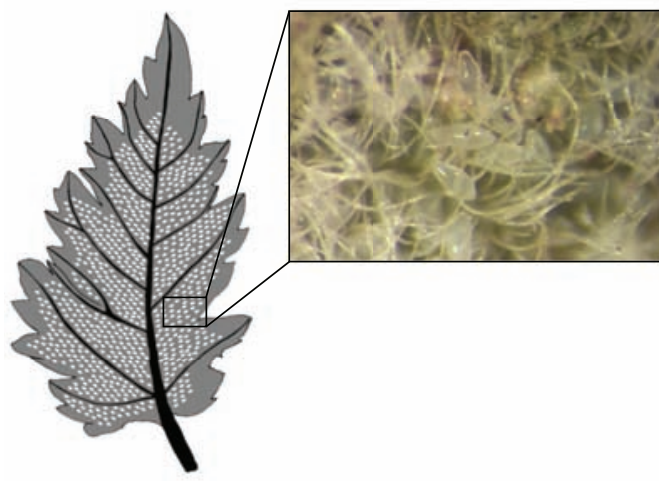

(d)

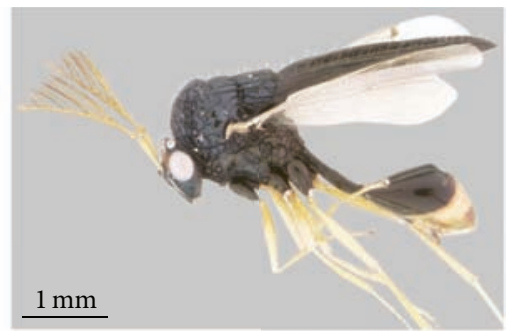

(b)

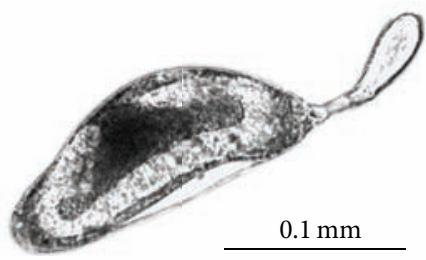

(e)

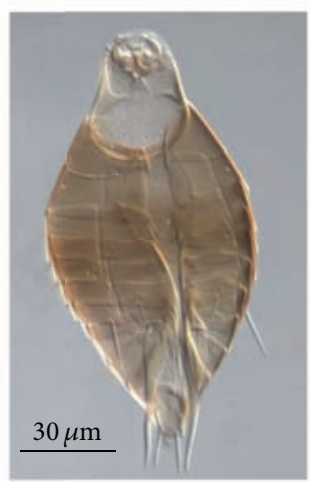

(f)

Figure 7: Neolirata daguerrei: (a) habitus (female); (b) habitus (male). Biology and immature stage of N. daguerrei: (c) habitat; (d) underside of leaf of Urvillea chacoensis with eggs (eggs represented in white area and magnified); (e) egg; (f) planidia. Figures extracted from [15].

Although host ants were not located in the area, the host has been reported as Solenopsis quinquecuspis Forel (Myrmicinae) [27].

Discussion. Plants used for oviposition also include Ilex paraguayensis A.St.-Hil. (Aquifoliaceae) (Yerba Mate) and Olea europaea L. (Oleaceae) (Olive) for which Orasema is considered as a potential pest $[50,57]$. Orasema aenea was found on both T. stans and Vaccinium corymbosum L. (Ericaceae) (blueberry), with the latter association recorded by Varone and Briano [29].

3.7.2. Orasema argentina Gemignani. It is associated with Pheidole nitidula Emery (Myrmicinae) $[6,17]$.

3.7.3. Orasema salebrosa Heraty. It is associated with Solenopsis invicta Buren, S. macdonaghi Santschi and S. richteri Forel (Myrmicinae) [11, 27].
3.7.4. Orasema simplex Heraty. It is associated with Solenopsis richteri, S. invicta, and S. quinquecuspis (Myrmicinae) $[11,27]$. Varone and Briano reported Zea mays L., Glycine max L., Vinca rosae L., Citrus limon (L.) Burn, Capsicum annuum L., Smilax campestris Griseb, Paspalum unispicatum (Scribn. \& Merr.) Nash, P. denticulatum Trin., P. notatum Fluegge, P. dilatatum Poir, Grindelia pulchella Dann., Stevia aff. entreriensis Hieron, Eupatorium aff. laevigatum L., Sesbania virgata (Cav.) Pers., Asclepias curassavica L., Verbena montevidensis Spreng., Sida rhombifolia L., and Stemodia aff. lanceolata Benth. with oviposition marks of Orasema simplex in nonchoice laboratory tests and in field surveys [29].

3.7.5. Orasema susanae Gemignani. It is associated with Pheidole near tetra Creighton [6].

3.7.6. Orasema worcesteri (Girault). It is associated with Pheidole radoszkowskii Mayr (Myrmicinae) (=P. nitidula) [17]. 


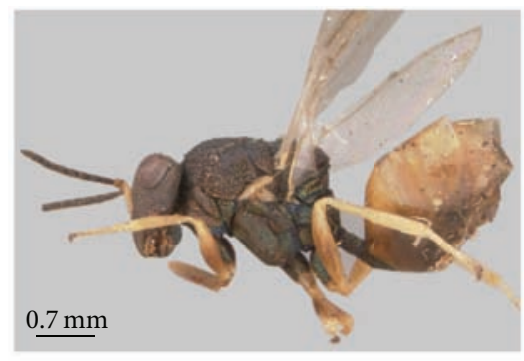

(a)

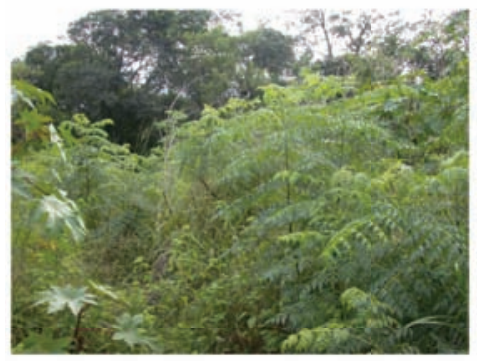

(c)

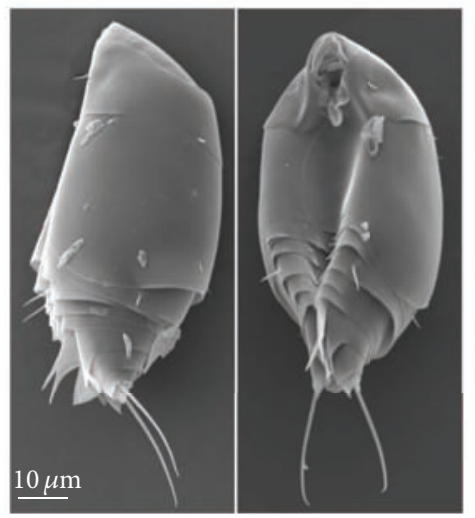

(f)

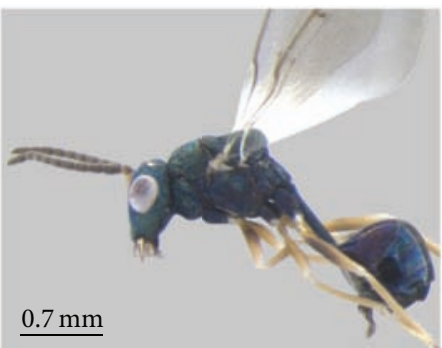

(b)

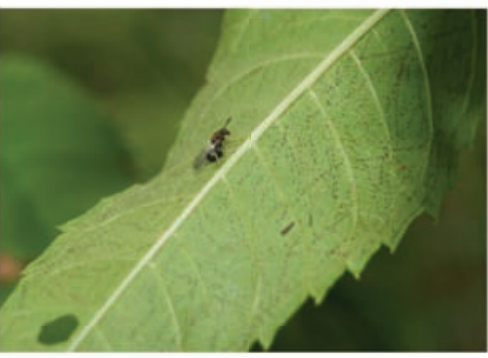

(d)

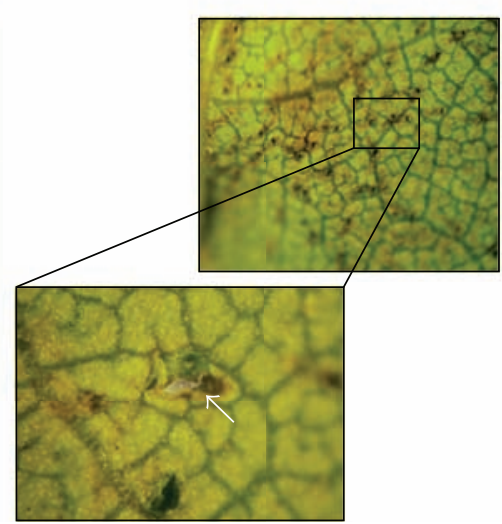

(e)

Figure 8: Orasema aenea: (a) habitus (female); (b) habitus (male). Biology and immature stage of O. aenea: (c) habitat; (d) female of O. aenea ovipositing on leaf of Tecoma stans; (e) underside of leaf of T. stans with incisions (magnified area with egg extracted from incision); (f) planidia (lateral and ventral).

3.7.7. Orasema xanthopus (Cameron). Various aspects related to its biology were recorded by several authors [11, 28, 3039]. Orasema xanthopus is associated with several species of Solenopsis, such as S. invicta [11, 27, 32-35, 39, 58], S. quinquecuspis [27], S. richteri [33], and the S. saevissima (Smith) complex $[6,11,35]$.

3.7.8. Orasema sp. Several females were collected in Villa Vil (Catamarca) ovipositing into the stem tissue below the flower buds and along the petiole and midrib of leaves of Lantana xenica Moldenke (Verbenaceae).

3.8. Thoracantha Latreille. This genus is comprised of three species, Thoracantha anchura Walker (Brazil), T. spegazzinii (Gemignani) (Argentina), and T. striata Perty (Argentina and Brazil) [8].
3.8.1. Thoracantha spegazzinii (Gemignani). A single female was collected on a flower of a Malvaceae. This data was included on the holotype label but not used in the original description of the species by Gemignani [17].

3.8.2. Thoracantha striata Perty. Heraty observed females ovipositing in patches on the underside of leaves of Lantana sp. (Verbenaceae); oviposition took place over 1-2 hours. Eggs and planidia were obtained [8].

\section{Conclusion}

Eucharitidae are found in almost all biogeographic regions in northern Argentina (Figure 9). Most genera are distributed in the Chaco ecoregion and the transition between Chaco and Yungas, but more surveys are necessary in the Monte and Pampa ecoregions, and in those it was areas never 

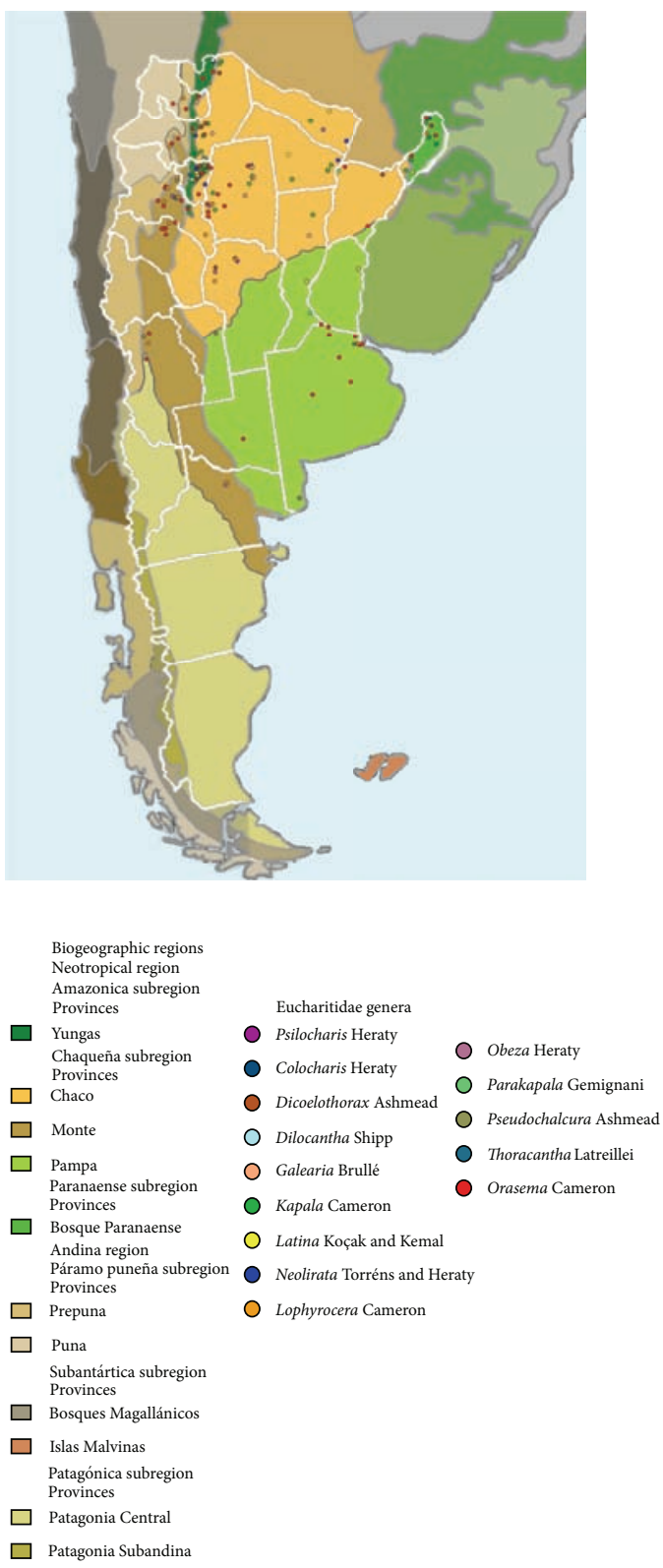

FIgURE 9: Distribution of genera of Eucharitidae in Argentina.

surveyed for eucharitids including Central Patagonia and Prepuna. Herein we presented a new record for Kapala sulcifacies (Cameron) from Salta (Rosario de la Frontera, 20/03/2003; one female and two males deposited in Instituto Fundación Miguel Lillo, Tucumán, Argentina), Lophyrocera plagiata (Walker) from Misiones (Mado, Puerto Magdalena, 23/10/1964; one female deposited in American Museum of Natural History, NY, USA) and Obeza semifumipennis (Girault) from Formosa (Pirané, 31/12/1948; two males deposited in Instituto Fundación Miguel Lillo, Tucumán, Argentina).

Although we have detailed information for most genera, little or nothing is known about the biology of many species. Host relationships were summarized by Heraty [8], Lachaud and Pérez-Lachaud [59], and Lachaud et al. [42]. Herein we presented a new host association for Galearia latreillei from Ectatomma brunneum and confirm the association of Latina rugosa with Odontomachus chelifer suggested by Torréns et al. [25]. Of the remaining genera present in Argentina, ant host relationships can be inferred from species found elsewhere in South and Central America. Generally, it is expected that in Argentina, Orasema (Oraseminae) are exclusively found on Myrmicinae, the genera Lophyrocera, Obeza, and Pseudochalcura attack Camponotini (Formicinae), and the remaining genera in the Kapala clade all attack either Ectatomminae or Ponerinae $[8,9,11,12,23,26,27,29,42,43,59]$.

Eucharitidae utilize a variety of distinct methods for oviposition. Oraseminae oviposit into incisions made in leaf tissues $[2,5,49,52]$. Damage to the leaves can be caused by scaring of the plant tissue [7] or through secondary infections caused by the punctures [50]. Because of this, Orasema have been considered as potential pests of banana, citrus, olive, tea, and yerba mate $[30,31,48,50,52,53]$. However, they are never regarded as a continuing pest problem. In contrast, Eucharitinae oviposit either on the undersides of the leaves, into fruits or into the bracts of flower buds, without causing cosmetic damage to the plants. However, as parasitoids of Ectatomma, they might have a negative impact on ants that are potential biological control agents [60]. Importantly, various details of the oviposition behavior, plant and ant host choice, behavior of the planidia both within and outside of the nest, and development within the nest are all key pieces of information to provide a better understanding of how the eucharitids gain access and specialize on their particular ant host group.

\section{Acknowledgments}

The author would like to thank J. M. Heraty and P. Fidalgo for their help in all his studies and Elizabeth Murray for constructive comments and suggestions of this paper. This investigation was made possible through funding by the Projects PIP6361 from CONICET and PICT 01238 provided by Agencia Nacional de Promoción Científica y Tecnológica. He dedicates this paper to the memory of Emma "Chongui" Wuscovi who supported him at all times in his Ph.D. degree.

\section{References}

[1] C. P. Clausen, "The immature stages of the Eucharidae," Proceedings of the Entomological Society of Washington, vol. 42, no. 8, pp. 161-170, 1940.

[2] C. P. Clausen, "The oviposition habits of the Eucharidae (Hymenoptera)," Journal of the Washington Academy of Sciences, vol. 30, no. 12, pp. 504-516, 1940.

[3] C. P. Clausen, “The habits of the Eucharidae," Psyche, vol. 48, pp. 57-69, 1941.

[4] J. M. Heraty, "A revision of the Nearctic Eucharitinae (Hymenoptera: Chalcidoidea: Eucharitidae)," Proceedings of the Entomological Society of Ontario, vol. 85, pp. 61-103, 1985.

[5] J. M. Heraty, "Classification and evolution of the Oraseminae in the Old World, with revisions of two closely related genera of Eucharitinae (Hym: Eucharitidae)," Life Sciences Contributions (Royal Ontario Museum), vol. 157, pp. 1-174, 1994. 
[6] J. M. Heraty, "Biology and importance of two eucharitid parasites of Wasmannia and Solenopsis," in Exotic Ants: Biology, Impact and Control of Introduced Species, D. Williams, Ed., pp. 104-120, Westview Press, Boulder, Colo, USA, 1994.

[7] J. M. Heraty, "Phylogenetic relationships of Oraseminae (Hymenoptera: Eucharitidae)," Annals of the Entomological Society of America, vol. 93, no. 3, pp. 374-390, 2000.

[8] J. M. Heraty, "A revision of the genera of Eucharitidae (Hymenoptera: Chalcidoidea) of the world," Memoirs of the American Entomological Institute, vol. 68, pp. 1-367, 2002.

[9] J. M. Heraty and K. N. Barber, "Biology of Obeza floridana (Ashmead) and Pseudochalcura gibbosa (Provancher) (Hymenoptera: Eucharitidae)," Proceedings of the Entomological Society of Washington, vol. 92, no. 2, pp. 248-258, 1990.

[10] C. P. Clausen, "The biology of Schizaspidia tenuicornis Ashm., a eucharid parasite of Camponotus," Annals of the Entomological Society of America, vol. 16, pp. 195-217, 1923.

[11] J. M. Heraty, D. P. Wojcik, and D. P. Jouvenaz, "Species of Orasema parasitic on the Solenopsis saevissima-complex in South America (Hymenoptera: Eucharitidae, Formicidae)," Journal of Hymenoptera Research, vol. 2, no. 1, pp. 169-182, 1993.

[12] G. Pérez-Lachaud, J. M. Heraty, A. Carmichael, and J.-P. Lachaud, "Biology and behavior of Kapala (Hymenoptera: Eucharitidae) attacking Ectatomma, Gnamptogenys, and Pachycondyla (Formicidae: Ectatomminae and Ponerinae) in Chiapas, Mexico," Annals of the Entomological Society of America, vol. 99, no. 3, pp. 567-576, 2006.

[13] S. C. Buys, R. Cassaro, and D. S. Alomon, "Biological observations on Kapala Cameron 1884 (Hymenoptera Eucharitidae) in parasitic association with Dinoponera lucida Emery 1901 (Hymenoptera Formicidae) in Brazil," Tropical Zoology, vol. 23, no. 1, pp. 29-34, 2010.

[14] J. Torréns, Estudios de Biología y Taxonomía de Eucharitidae (Hymenoptera: Parasitica) de Argentina, parasitoides de Formicidae (Hymenoptera: Aculeata) [Ph.D. thesis], Universidad Nacional de Tucumán, Tucumán Province, Argentina, 2010.

[15] J. Torréns and J. M. Heraty, "A new genus of Eucharitidae (Hymenoptera: Chalcidoidea), with notes on life history and immature stages," Zootaxa, vol. 3630, no. 2, pp. 347-358, 2013.

[16] J. Torréns, "Primer registro de Colocharis (Chalcidoidea: Eucharitidae) en la Argentina y descripción de una nueva especie," Revista de la Sociedad Entomológica Argentina, vol. 71, no. 3-4, pp. 215-218, 2012.

[17] E. V. Gemignani, "La familia " Eucharidae" (Hymenoptera: Chalcidoidea) en la República Argentina," Anales del Museo Nacional de Historia Natural, vol. 37, pp. 477-493, 1933.

[18] E. V. Gemignani, "Nueva nota sobre la familia Eucharidae (Hymenoptera: Chalcidoidea)," Anales del Museo Nacional de Historia Natural, vol. 39, pp. 159-166, 1937.

[19] E. V. Gemignani, "Nuevas especies de la familia Eucharidae (Insecta, Hymenop. Chalcid.)," Comunicaciones del Museo Argentino de Ciencias Naturales, "Bernardino Rivadavia", vol. 1, pp. 1-15, 1947.

[20] J. J. Morrone, "Biogeografía de América Latina y el Caribe, vol. 3 of M\&T-Manuales \& Tesis SEA, Sociedad Entomológica Aragonesa, Zaragoza, Spain, 2001.

[21] C. Bertonatti and J. Corcuera, Situación Ambiental Argentina, Fundación Vida Silvestre Argentina, Buenos Aires, Argentina, 2000.
[22] J. Torréns and J. M. Heraty, "Description of the species of Dicoelothorax Ashmead (Chalcidoidea, Eucharitidae) and biology of D. platycerus Ashmead," ZooKeys, vol. 165, pp. 33-46, 2012.

[23] J. M. Heraty and J. B. Woolley, "Separate species or polymorphism: a recurring problem in Kapala (Hymenoptera: Eucharitidae)," Annals of the Entomological Society of America, vol. 86, no. 5, pp. 517-531, 1993.

[24] J. M. Heraty and D. C. Darling, "Comparative morphology of the planidial larvae of Eucharitidae and Perilampidae (Hymenoptera: Chalcidoidea)," Systematic Entomology, vol. 9, no. 3, pp. 309-328, 1984.

[25] J. Torréns, J. M. Heraty, and P. Fidalgo, "Biology and description of a new species of Laurella Heraty (Hymenoptera: Eucharitidae) from Argentina," Proceedings of the Entomological Society of Washington, vol. 109, no. 1, pp. 45-51, 2007.

[26] J. Torrens, J. M. Heraty, and P. Fidalgo, "Biology and description of a new species of Lophyrocera Cameron (Hymenoptera: Eucharitidae) from Argentina," Zootaxa, no. 1871, pp. 56-62, 2008.

[27] L. Varone, J. M. Heraty, and L. A. Calcaterra, "Distribution, abundance and persistence of species of Orasema (Hym: Eucharitidae) parasitic on fire ants in South America," Biological Control, vol. 55, no. 1, pp. 72-78, 2010.

[28] R. K. Vander Meer, D. P. Jouvenaz, and D. P. Wojcik, "Chemical mimicry in a parasitoid (Hymenoptera: Eucharitidae) of fire ants (Hymenoptera: Formicidae)," Journal of Chemical Ecology, vol. 15, no. 8, pp. 2247-2261, 1989.

[29] L. Varone and J. Briano, "Bionomics of Orasema simplex (Hymenoptera: Eucharitidae), a parasitoid of Solenopsis fire ants (Hymenoptera: Formicidae) in Argentina," Biological Control, vol. 48, no. 2, pp. 204-209, 2009.

[30] A. Tocchetto, "Bicho costureiro," Revista Agronomica, Porto Alegre, vol. 6, pp. 587-588, 1942.

[31] F. S. Roberts, "Insects affecting banana production in central America," in Proceedings of the 10th International Congress of Entomology, vol. 3, pp. 411-415, 1958.

[32] A. Silveira-Guido, "Investigations on the biology and biological control of the fire ant, Solenopsis saevissima richteri Forel in Uruguay," Annual Report, Departamento de Sanidad Vegetal, Facultad de Agronomía, Universidad de la República, Montevideo, Uruguay, 1962.

[33] A. Silveira-Guido, P. San-Martin, C. Crisci-Pisano, and J. Carbonnell-Bruhn, "Investigations on the biology and biological control of the fire ant, Solenopsis saevissima richteri Forel in Uruguay," Third Report, Departamento de Sanidad Vegetal, Facultad de Agronomía, Universidad de la República, Montevideo, Uruguay, 1964.

[34] R. N. Williams, "Insect natural enemies of fire ants in South America with several new records," in Proceedings of the Tall Timbers Conference on Ecology, Animal Control and Habitat Management, vol. 7, pp. 123-134, 1980.

[35] R. N. Williams and W. H. Whitcomb, "Parasites of fire ants in South America," in Proceedings of the Tall Timbers Conference on Ecology, Animal Control and Habitat Management, vol. 5, pp. 49-59, 1973.

[36] D. P. Wojcik, "Status and search for natural control agents in South America," in Proceedings of the Annual Fire Ant Conference, vol. 5, pp. 29-37, 1986.

[37] D. P. Wojcik, "Survey for biocontrol agents in Brazil: a final report, with comments on preliminary research in Argentina," 
in Proceedings of the Imported Fire Ant Conference, pp. 50-62, Athens, Ga, USA, 1988.

[38] D. P. Wojcik, "Behavioural interactions between ants and their parasites," The Florida Entomologist, vol. 72, no. 1, pp. 43-51, 1989.

[39] D. P. Wojcik, D. P. Jouvenaz, W. A. Banks, and A. C. Pereira, "Biological control agents of fire ants in Brazil," in Chemistry and Biology of Social Insects, J. Eder and H. Rembold, Eds., pp. 627-628, J. Peperny, München, Germany, 1987.

[40] A. P. L. Digilio and P. R. Legname, "Los árboles indígenas de la provincia de Tucumán,” Opera Lilloana, vol. 15, pp. 1-283, 1966.

[41] D. M. Lapola, W. F. Aantonalli Jr., and E. Giannotti, "Arquitetura de ninhos da formiga neotropical Ectatomma brunneum $\mathrm{F}$. Smith, 1858 (Formicidae: Ponerinae) em ambientes alterados," Revista Brasileira de Zoociências, vol. 5, no. 2, pp. 177-188, 2003.

[42] J.-P. Lachaud, P. Cerdan, and G. Pérez-Lachaud, "Poneromorph ants associated with parasitoid wasps of the genus Kapala Cameron (Hymenoptera: Eucharitidae) in French Guiana," Psyche, vol. 2012, Article ID 393486, 6 pages, 2012.

[43] G. Pérez-Lachaud, J. A. López-Méndez, and J. P. Lachaud, "Eucharitid parasitism of the Neotropical ant Ectatomma tuberculatum: parasitoid co-occurrence, seasonal variation, and multiparasitism," Biotropica, vol. 38, no. 4, pp. 574-576, 2006.

[44] J. Pensiero, J. D. Muñoz, and V. Martinez, "Alternativas de sustentabilidad del bosque nativo del Espinal. Área Etnobotánica," Proyecto de Investigación Aplicada a los Recursos Forestales Nativos (PIARFON), January 2013, http://www.ambiente.gov .ar/?idarticulo $=949$.

[45] D. W. Davidson, "Ecological studies of neotropical ant gardens," Ecology, vol. 69, no. 4, pp. 1138-1152, 1988.

[46] M. S. Ferrucci, "Sapindaceae Juss. Guías ilustradas de clases," Aportes Botánicos de Salta. Serie Flora, vol. 7, no. 4, pp. 1-44, 2004.

[47] W. M. Wheeler, "The polymorphism of ants, with an account of some singular abnormalities due to parasitism," Bulletin of the American Museum of Natural History, vol. 23, pp. 1-93, 1907.

[48] G. C. Wheeler and E. W. Wheeler, "New hymenopterous parasites of ants (Chalcidoidea: Eucharidae)," Annals of the Entomological Society of America, vol. 30, no. 1, pp. 163-175, 1937.

[49] H. L. Parker, "Oviposition habits and early stages of Orasema sp., Proceedings of the Entomological Society of Washington, vol. 44, no. 7, pp. 142-145, 1942.

[50] J. C. Nicolini, "La avispa costurera y la tuberculosis del olivo," Revista Agronomica, Porto Alegre, vol. 20, pp. 35-36, 1950.

[51] A. F. van Pelt, "Orasema in nests of Pheidole dentata Mayr (Hymenoptera: Formicidae)," Entomological News, vol. 61, no. 6, pp. 161-163, 1950.

[52] G. M. Das, "Preliminary studies on the biology of Orasema assectator Kerrich (Hym., Eucharitidae), parasitic on Pheidole and causing damage to leaves of tea in Assam," Bulletin of Entomological Research, vol. 54, no. 3, pp. 373-379, 1963.

[53] G. J. Kerrich, "Descriptions of two species of Eucharitidae damaging tea, with comparative notes on other species (Hym., Chalcidoidea)," Bulletin of Entomological Research, vol. 54, no. 3, pp. 365-372, 1963.

[54] J. B. Johnson, T. D. Miller, J. M. Heraty, and F. W. Merickel, "Observations on the biology of two species of Orasema (Hym.: Eucharitidae)," Proceedings of the Entomological Society of Washington, vol. 88, no. 3, pp. 542-549, 1986.
[55] B. Carey, K. Visscher, and J. Heraty, "Nectary use for gaining access to an ant host by the parasitoid Orasema simulatrix (Hymenoptera, Eucharitidae)," Journal of Hymenoptera Research, vol. 27, pp. 47-65, 2012.

[56] J. M. Heraty, Classification and evolution of the Oraseminae (Hymenoptera: Eucharitdae) [Ph.D. thesis], Texas A\&M University, College Station, Tex, USA, 1990.

[57] A. B. Gahan, "A contribution to the knowledge of the Eucharidae (Hymenoptera: Chalcidoidea)," Proceedings of the United States National Museum, vol. 88, pp. 425-458, 1940.

[58] L. de Santis, "Una nueva especie de "Orasema" del Uruguay (Hymenoptera: Eucharitidae)," Revista Sociedad Entomológica Argentina, vol. 7, pp. 1-3, 1968.

[59] J.-P. Lachaud and G. Pérez-Lachaud, "Diversity of species and behavior of hymenopteran parasitoids of ants: a review," Psyche, vol. 2012, Article ID 134746, 24 pages, 2012.

[60] J.-P. Lachaud and G. Pérez-Lachaud, "Impact of natural parasitism by two eucharitid wasps on a potential biocontrol agent ant in southeastern Mexico," Biological Control, vol. 48, no. 1, pp. 92-99, 2009. 

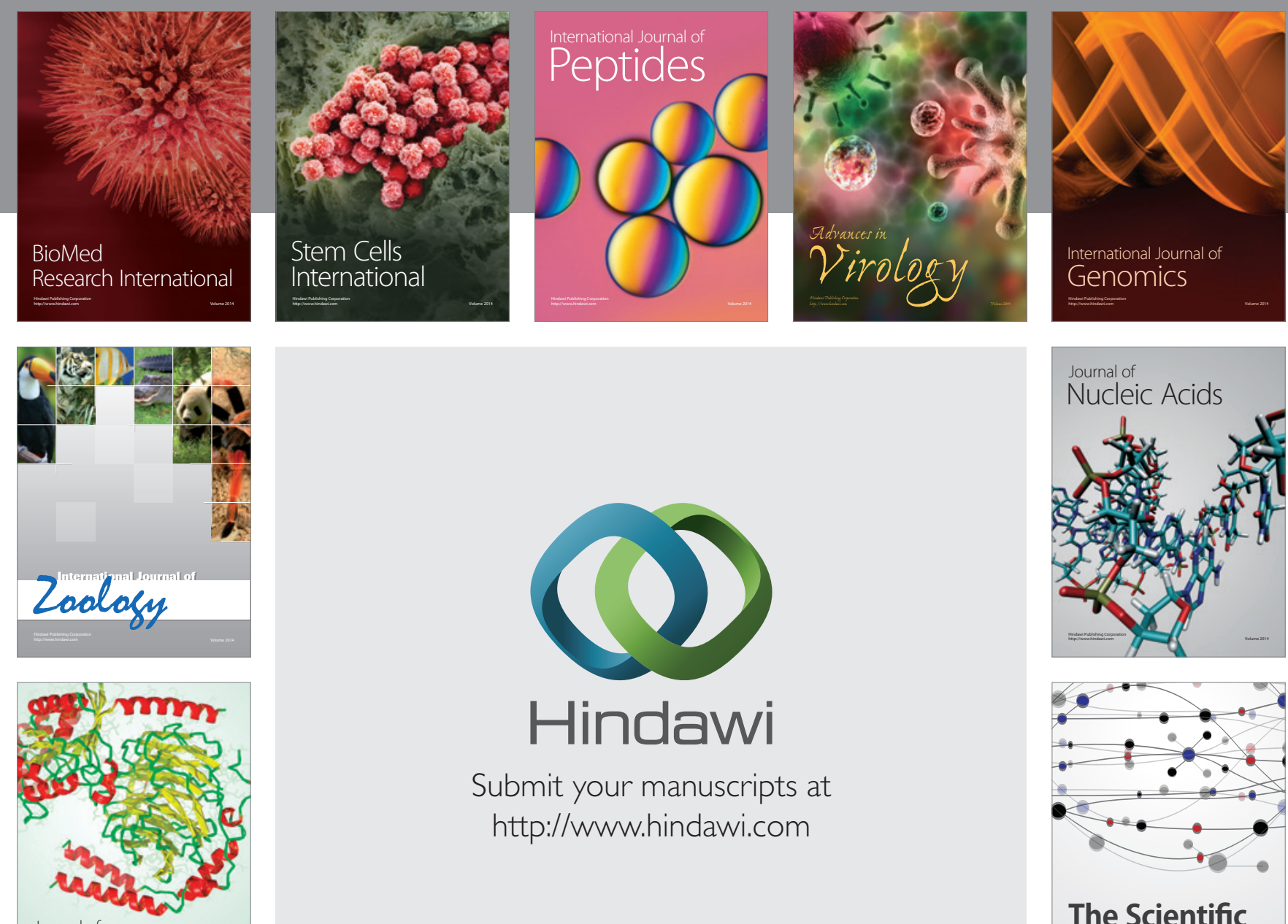

Submit your manuscripts at

http://www.hindawi.com

Journal of
Signal Transduction
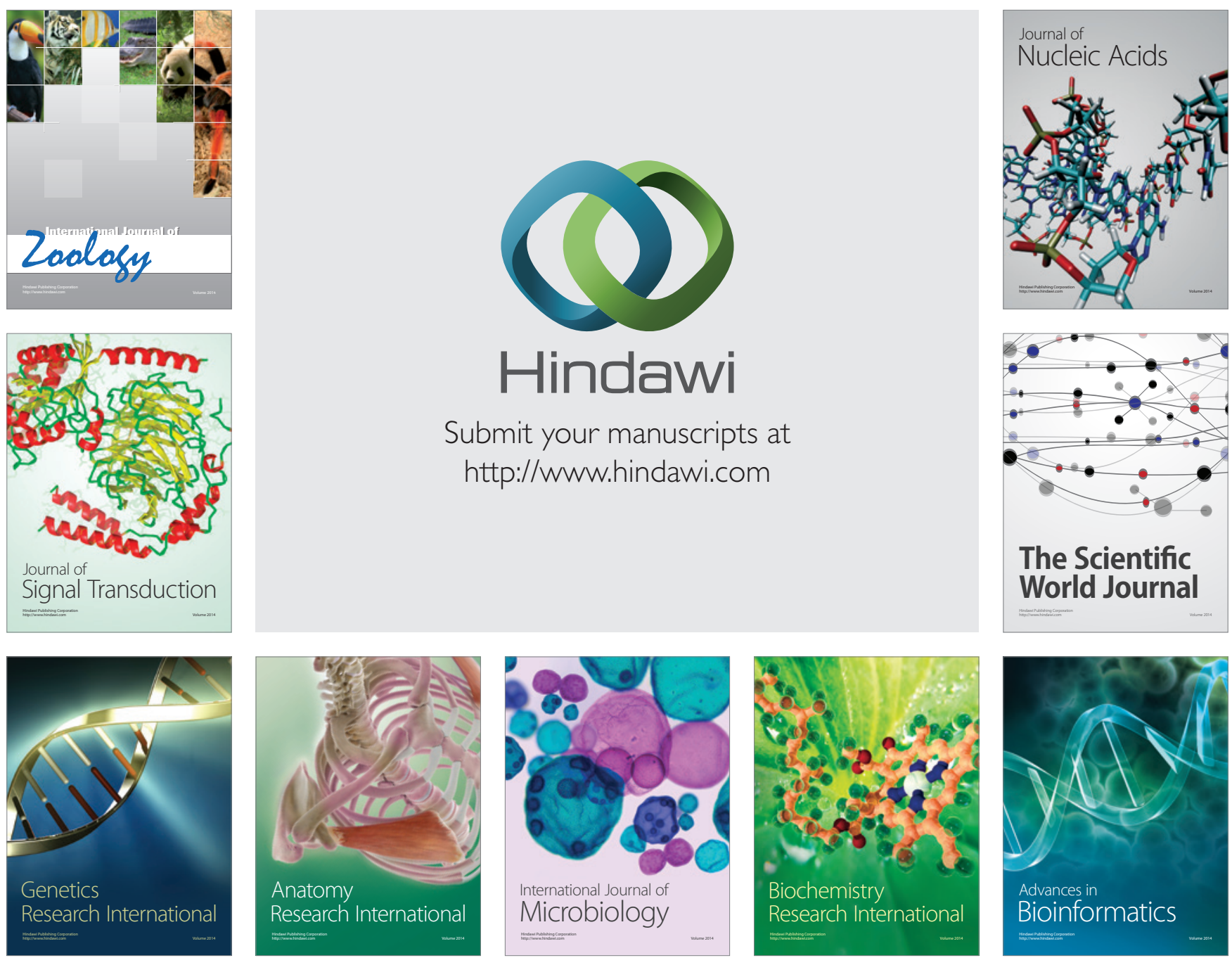

The Scientific World Journal
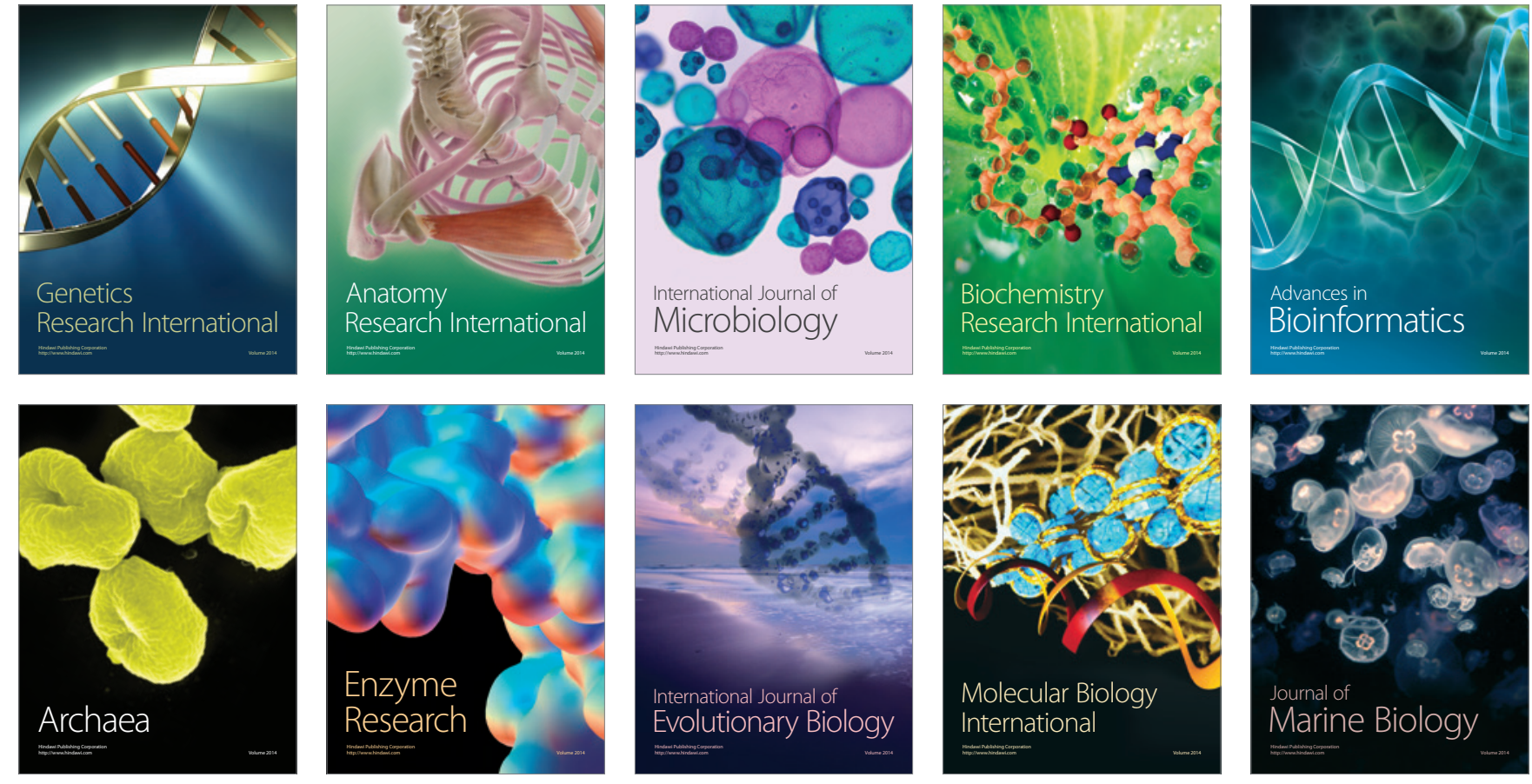